\title{
Real Gross Domestic Growth Determinants in an Oil Revenue Dependent Country: An Assessment of Nigeria's Exchange Rate and Interest Rate
}

\author{
Felicia Akujinma Anyanwu, Patrick Kanayo Adigwe, Amalachukwu Chijindu Ananwude* \\ Department of Banking and Finance, Nnamdi Azikiwe University, Awka, Nigeria
}

Email address:

amalision4ltd@yahoo.com (A. C. Ananwude)

${ }^{*}$ Corresponding author

\section{To cite this article:}

Felicia Akujinma Anyanwu, Patrick Kanayo Adigwe, Amalachukwu Chijindu Ananwude. Real Gross Domestic Growth Determinants in an Oil Revenue Dependent Country: An Assessment of Nigeria's Exchange Rate and Interest Rate. Science Journal of Energy Engineering. Vol. 5, No. 4, 2017, pp. 78-86. doi: 10.11648/j.sjee.20170504.11

Received: June 30, 2017; Accepted: July 17, 2017; Published: October 23, 2017

\begin{abstract}
The determinants of real gross domestic product growth in Nigeria was ascertained in this study. The research was motivated by 1.53 percent decline in real gross domestic product growth rate in 2016 coupled with the foreign exchange crisis that engulfed the economy. Specifically, the study determined whether exchange rate and interest rate predict real gross domestic product growth using secondary data obtained from Central Bank of Nigeria for the period 1980 to 2016. Aside testing for stationarity of the data and diagnosing the model to meet standard econometric postulations, the Granger Causality prediction estimation was employed to realize the objective of the research. Firstly, by the application of Johansen cointegration and ARDL methodology, the study identify that exchange rate and interest rate are not co-integrated/related with real gross domestic product growth. Secondly, the multiple regression estimated via ARDL shows that exchange rate and interest rate have negative but insignificant relationship with real gross domestic product growth. Finally, the study empirically found that exchange rate and interest rate are not determinants of real gross domestic product growth in Nigeria. To strengthen the value of the local currency against the US dollar in particular, and other currencies of the world, a well-managed foreign exchange floating system is preferred. Diversification from oil to non-oil policies should be pursued with vigour with the view of aggressively down playing importation to reduce the pressure on forex which jolts up exchange rate position adversely.
\end{abstract}

Keywords: Real Gross Domestic Product, Exchange Rate, Interest Rate

\section{Introduction}

The exchange and interest rate policy of the Federal Government of Nigeria have continued to dominate the economic cycle, presumably on Nigeria's inability to produce what they consume and wholly relies on revenue from oil exports. The exchange rate policy seems to be the life-wire of the Nigeria economy following the introduction of structural adjustment programme in 1986 which mark the starting point of the depreciation of the local currency against the US dollar [1]. With this, it could be adduced that what exchange rate and interest rate stability is to domestic balance of trade is what it is to external balance of trade which grows the real gross domestic product. Different exchange rate regimes and interest rate policies have been adopted at different times to meet up the nation's objective of economic growth and development. Understandably, exchange rate is the rate at which a country's currency exchanges for another. Operationally, the price of one unit of a foreign currency say 1 US dollar in terms of the local currency: 1 Nigeria Naira. The exchange rate of one unit of the Nigerian Naira to 1 US dollar as at $31^{\text {st }}$ May, 2017 was approximately $\$ 400$ while interest rate charged by deposit money banks after factoring handling charges, insurance fees, management charges, etc. is over $25 \%$ thus making it difficult for entrepreneurs to seek credit from banks. In the foreign exchange market, a currency may be exchanged at different rates with other currencies of the world owing to the forces of demand and supply. In a fixed exchange rate and/or interest rate regime, the monetary authority ties directly to the value of another 
currency to ensure certainty of effect/predictability on trade and/or fixes the interest rate while the floating system allows the forces of demand and supply to determine the exchange rate.

The application of either regimes have effect on the economy. For instance, relying assiduously on [2], during the era of fixed exchange rate system which anchors on international values for the purpose of trade, each currency was selling at a par and in turn, tied in relation to gold as set by International Monetary Fund in relation to the US dollar. But in practice, slightly varied exchange rate prevailed until 1971 when the US suspended the convertibility due to serious balance of payment deficit she had. Consequently, the US dollar could no longer be freely exchanged for gold at a fixed price. With the prevailing circumstance, the fixed exchange rate collapsed and gave birth to the floating exchange rate system. In Nigeria, the fixed exchange rate system failed to accelerate economic growth as proposed leading to a reversal despite a number of programme interventions such as Structural Adjustment Programme of 1986, privatization and commercialization of public enterprises. The objective and ambition of any nation is to maintain a stable level of exchange and interest rate capable of reducing inflation, currency depreciation and precursors of modern devaluation. However, history and records have it that mismanagement of exchange rate have resulted in serious macroeconomic instability predominantly in developing countries and not excluding Nigeria. The current level of volatility in exchange and interest rate is unbearable in the country. This contributed partly to the recession experienced in the economy which started in 2016. Empirical studies have revealed that exchange and interest rate crisis travelled hand in hand in the overwhelming majority of episode of currency crisis. This should hardly come as a surprise given the prominent exchange rate crisis in some countries of the world at some specific point in time: Mexico (1994), Asia (1997), Russia (1998), Brazil (1999), and Argentina (2001) among other countries [3].

In consideration for external economic environment in modelling domestic economy by ensuring stable exchange rate regime, the linkage between exchange rate, interest rate and real output of an economy as explained by the Keynesian model of open economy cannot be ignored. An open economy like Nigeria exhibits high dependence on external factors such as trade, production, capital flows, technology and consumption of imported goods. Having this in mind and coupled with its implication on the economy, this study emphatically seek to ascertain whether or not exchange rate and interest rate are important determinants of real gross domestic product growth in Nigeria as well as the long run relationship between exchange rate, interest rate and real gross domestic product growth.

For apprehensible of readers, this paper was structured into sections. Section one gave a precise background to the study otherwise called introduction. Section two dwelt on the review of related literature. Section three covered the methodological approach applied and section four the estimation results and interpretations. Finally, section five concluded the study and proffered recommendation for consideration and implementation by decision makers.

\section{Literature Review}

Real gross domestic product is a concept that measures the value of goods and services produced over a given period of time. Simply put, it is a measure of domestic production by an economy within a stated period of time and evaluated in monetary value. Real gross domestic product is widely calculated on purchasing power parity and taking into consideration the probable effect of inflation. The contribution of developed countries gross domestic product e.g. China, United States of America, United Kingdom and Germany to global gross domestic product are known and very substantial compared to other developed and emerging economies. Taking a clue from this, it would be ideal to determine Nigeria's share of world gross domestic product. However, the indices for computation of any country's share of global gross domestic product may be constrained by chronic manoeuvring of data. From a country specific dimension, the external account is considered more reliable than other series of macroeconomic activities [4].

Exchange rate is simply seen as the value of a country's currency in terms of another country currency. The mechanism of adopting a particular system of exchange rate is dependent on the affected country in her conduct of international trade and settlement of other maturing obligations among others. Fixed exchange rate adoption allows the government peg its exchange rate against another country. Contrary to that is the flexible system in which exchange rate is determined by the interaction of demand and supply in the market.

Interest rate in this paper addresses the rate at which deposit money banks lend to the economy. Credit facilities are gotten from deposit money banks at a rate as high as $27 \%$ (this include all fees such as handling fee, processing/management fee, insurance fee, etc.). The interest rate in Nigeria has been adjudged to be among the highest in the world. This high interest rate deter productive economic activities as investors shy away from bank loans. Despite the high interest rate, deposit money banks themselves are reluctant to lend to small and medium scale enterprises and agriculture among others. They see this sectors as most vulnerable to risk and prefer to lend to the oil and gas sector due to their assets base coupled with the fact that oil is the main source of revenue to Nigeria. The fall in price of oil price in the international market increased credit risk of banks as many oil and gas firms were not able to meet up with their obligations as at when due, some loans were restructured and rescheduled.

From theoretical consideration, theories such as purchasing power parity, interest rate parity theory, traditional flow theory, portfolio balance model have been modelled to discuss real gross domestic product, exchange rate and interest rate nexus. However, in this paper, we dwelt 
on traditional flow theory which focused on balance of payment, and then the interest rate parity theory that linked exchange rate and interest rate. Interest rate parity from the point of view of [4], states that in equilibrium, the difference in interest rate between two countries is equal to the difference between the forward and spot rates of exchange, that is, the difference between the spot rate and the forward rate allows for the difference in interest rate. In a modern economy, the interest rate is determined by the money market. That notwithstanding, government intervenes through adjustments in minimum rediscounting rate in a bid to prevent interest rate from going on the high side. The current minimum rediscounting rate of $14 \%$ is seen as the biggest contributory factor to the high interest rate of $27 \%$ charged by deposit money banks in Nigeria. The traditional flow theory in a free exchange rate system states that balance of payment conceptually and practically should determine the value of a country's currency or exchange rate. In reality, the currency of a nation can unarguably appreciate and maintain stability only if there is a favourable or surplus balance of payment and depreciate when there is deficit/unfavourable balance of payment. It is usually the magnitude of pressure in the demand of foreign exchange that causes outflow in the foreign exchange market to exceed supply of foreign exchange. The direct effect of this scenario is the depreciation in the value of domestic currency relative to foreign currency with an implication of export of goods and services increasing. When the exchange rate is above equilibrium rate in a favourable balance of payment position, to restore equilibrium or move towards equilibrium, export of goods and services increasingly decline. Nevertheless, determining factors may include the domestic elasticity of demand for imports and the elasticity of supply for exports [5]. In period of high volatility in exchange rate in Nigeria, the Central Bank of Nigeria has a policy to ensuring stability of the exchange rate through policy intervention in the foreign exchange market using the nation's external reserves. The external reserve has provided a relationship of defence to the value of the local currency in the foreign exchange market by pumping forex to bureau-de-change to meet up with the demand for foreign exchange. Over the years, the value of the local currency has been successfully managed within a band of $+/-3.0$ percent [6]. This is very important in the promotion of the country's international credit rating and the confidence the country has on its foreign exchange market.

Empirical evidences on the determinants of real gross domestic product in Nigeria is relevant considering the dynamism of the economy. Empirical literatures from around the globe were reviewed with the aim of knowing how exchange rate has affected/influenced real gross domestic product. Empirical studies on Nigeria started the review process where the impact of exchange rate and inflation on economic growth measured with real gross domestic product was ascertained by [7] using data for the period 1970 to 2005. The study adopted the Johansen co-integration and Engel-Granger Causality technique amidst stationarity test.
The result of the study revealed a unidirectional causality running from exchange rate to economic growth. However, this was countered by [8] who established no causal relationship between exchange rate and economic in Nigeria. Further analysis from [8] indicated a positive and insignificant relationship between exchange rate and economic growth in Nigeria which made the scholars to suggest for stability in exchange rate via diversification to other sources of foreign exchange such as agriculture, mining, etc. The study by [9] revealed that output has been indirectly affected by exchange rate depreciation in Nigeria and identified no evidence of a strong direct relationship between changes in exchange rate and output growth. In a recent study by [10] and [11], real gross domestic product was not affected by movements in exchange rate. This study is of the humble opinion based on prevailing circumstances in the economy that exchange rate depreciation in Nigeria has caused more harm than good. Even though [12] asserted that exchange rate had a greater impact on the economy when compared to interest rate adjustment, assiduously rely on a preceding research of [13], exchange rate has not significantly affected economic growth in Nigeria. In the experience of other countries in Africa, [14] established that economic growth in Côte d'Ivoire has been negatively affected by exchange rate volatility. In the same manner, [15] observed that Kenya's international competitiveness deteriorated owing to high volatility in exchange rate. Away from the continent of Africa, [16] proved that low fluctuation in exchange rate has enhanced economic growth in Bangladesh. For other developing countries in the globe, [17] showed that the effect of exchange rate fluctuations on economic growth are negative and significant. For developed countries like United States of America, United Kingdom, etc. studies have shown that their high level of economic growth is attributed to stability in exchange rate. Malaysia to be specific, [18] envisaged the positive and significant effect of low exchange rate volatility on economic growth. For high-growth economies of East Asia, [19] observed that keeping the real exchange rate at competitive levels can be critical for jump-starting growth.

Having looked at some previous studies on economic growth and exchange rate nexus, empirical evidences on interest rate and economic growth modelling were further ascertained. Starting from Nigeria, [20] restated the importance of interest rate in economic growth. [20] observed that interest rate has significant effect on economic growth and that the growth of the economy and interest rate adjustments are related in the long run. Similarly, [21] pointed out that in Nigeria, exchange rate is a significant monetary policy instrument that drive growth. [23] noted from Nigeria business environment that the relationship between interest rate and output is inverse in accordance with the standard growth theory and suggested for lower interest rate to tremendously enhance economic growth. The importance of low interest rate in developing economies to increase output have been also documented by [23] for Pakistan, [24] and [25] for Iran. The high interest rate in 
Nigeria is unbearable by investors who would rather source fund from families, relatives, friend and credit and thrift societies among others. Amidst high level of macroeconomic uncertainty in Nigeria, borrowing at a rate as high as $27 \%$ would be practically impossible to earn returns that will offset the interest charged for an average entrepreneur. With this, [26] proved that generalizing interest rate as equal either in developed or developing economies is cumbersome due to significant and un-comparable difference in social-economic belief, approaches and existing structures. Following the result of [26], [27] asserted that economic growth in Nigeria has been negatively impacted by high interest rate and accompanying high inflationary level. [28] for major industrial countries in the globe, explored the connection between interest rate and real gross domestic product of domestic economies and unveiled that high interest rates have a contractionary effect on economic growth, but such effect is on countries with fixed exchange rate system. From literature, it is vivid that high interest rate is detrimental for growth in developing countries, and based on Nigeria's business environment, developing the capital market for lower cost of fund becomes imperative. Subsequent to [29], it is a signal for monetary authority to adopt sustainable policies to lowering interest rate.

Results emanating from empirical studies conducted within the period the exchange rate crisis started: 2015 and consequent decline in real gross domestic product in 2016 are in the same direction. [31] reported that Nigeria's economic growth has been negatively affected by exchange rate depreciation over the years thus encouraging investment in domestic economy to improve real GDP requires government to prioritize the enhancement and promotion of a stable exchange rate and interest rate policy. [32] found a positive insignificant relationship between exchange rate and manufacturing sector output, hence exchange rate could not be said to have significantly improved manufacturing sector performance. [33] discovered that exchange rate crisis has deterred industrial performance in Nigeria at current but with stability and favourable exchange rate, Nigeria's industrial performance will be tremendously achieve stable growth in the long run. Estimating real exchange rate misalignment through computing deviations of the actual real exchange rate from a sustainable equilibrium path that is determined using the Behavioural Equilibrium Exchange Rate (BEER) approach of Edwards (1989), [34] found empirical support for a negative impact of exchange rate depreciation on economic growth of Nigeria. Though the monetary authority has initiated policies aimed at absorbing the influences of exchange rate fluctuation, [35] proved the existence of a positive but insignificant impact of exchange rate fluctuation on Nigerian economic growth in both long and short run. In the lieu of the empirical findings from studies between 2015 and 2016, stability of the exchange rate and reduced interest rate are suggested by scholars to cause upsurge in real GDP of Nigeria. That notwithstanding, studies prior to 2015 have also admonished monetary authority to allow the forces of demand and supply determine the exchange rate pattern. This resulted in shifting from fixed exchange rate regime to floating system by the Central Bank of Nigeria on $15^{\text {th }}$ June, 2016. This according to [36] will increase productive economic activities that will boost the real GDP. However, following the adverse effect of interest rate on real sector growth, [37] has maintained that reduction in minimum rediscounting rate would force interest rate to go down from its current rate of approximately $27 \%$.

\section{Method and Materials}

The Granger Causality technique was applied in ascertaining the determinants of real gross domestic product growth using secondary data from 1980 to 2016 as obtained from Central Bank of Nigeria statistical bulletin. The data were diagnosed of stationarity defects via The Argumented Dickey-Fuller (ADF) and Phillips Perron (PP). The long run relationship via Johansen methodology was assessed priori to ascertaining whether exchange rate and interest rate determine real gross domestic product growth or not.

\section{Model Estimation Specification}

Succeeding the Keynesian theory assumption that an economy is said to be efficient only when there is effective and efficient utilization of all resources, and the expression of economic growth as dependent on changes in exchange rate and interest rate, this study develop a model as:

$$
y=I R+E R
$$

Econometrically transforming the variables in (1), thus:

$$
y_{t}=\beta_{0}+\beta_{1} E R_{t}+\beta_{2} I R_{t}+\epsilon_{t}
$$

Where $y$ is the dependent variable representing real gross domestic product growth rate; $E R$ is exchange rate; $I R$ is interest rate; $\beta_{0}$ is the intercept coefficient; $\beta_{1}+\beta_{2}$ are the coefficients of exchange rate and interest rate which are the independent variables while $\epsilon_{t}$ is the error term in line with classical assumption of any econometric model to take into account of variable (s) not included in the regression model. The model was structured not to control the likely effect of other macroeconomic variable (s) that may influence real gross domestic product growth. Though it appears to be a departure from [30], but it is in anxiety of this research to statistically ascertain only the influence (if any) of exchange rate and interest rate based on Nigeria's economic environment.

\section{Estimation Results and Interpretations}

\section{Descriptive Attributes of Data}

The estimation of the model began with the descriptive characteristics of the variables presented in Table 1. The mean of the variables were divulged as 28959, 76.57 and 72.73 for real domestic product growth rate, exchange rate and interest rate respectively. The highest and lowest values are 69024 and 31.50 for real domestic product growth rate, 304.20 and 0.54 for exchange rate and 24.85 and 7.50 for interest rate. Respectively, the standard deviation are 20919, 
77.14 and 4.95 for real domestic product growth rate, exchange rate and interest rate. Judging from the standard deviation of exchange rate and interest rate, it is vivid that there was much volatility in exchange rate compared to interest rate. From the skewness statistic, all the variables were positively skewed to normality. Kurtosis envisages the leptokurtic nature of the variables except real domestic product growth rate with 2.24 which is less than the bench mark of 3.0.

Table 1. Descriptive Properties for Nigeria Data.

\begin{tabular}{|c|c|c|c|c|c|c|c|c|c|c|}
\hline & Mean & Median & Maximum & Minimum & Std Dev. & Skewness & Kurtosis & J. Bera & P-val. & Obs. \\
\hline $\mathrm{Y}$ & 28959 & 22333 & 69024 & 31.50 & 20919 & 0.46 & 2.24 & 2.19 & 0.33 & 37 \\
\hline ER & 76.57 & 22.05 & 304.20 & 0.54 & 77.14 & 0.77 & 3.04 & 3.64 & 0.16 & 37 \\
\hline IR & 17.32 & 17.50 & 29.80 & 7.50 & 4.95 & 0.09 & 3.31 & 0.19 & 0.91 & 37 \\
\hline
\end{tabular}

Source: Data output via E-views 9.0

\section{Sensitivity Analysis of Data}

To ensure that the model upheld to basic assumption of classical linear regression model, the model was diagnosed for heteroskedasticity, serial correlation, Ramsey specification and multicollinearity. The results of the sensitivity analysis of the data are summarized in Tables 2-5. Table 2 shows that the model is not associated with heteroskedasticity as evidence by the p-value of 0.25 (insignificant at 5\% level of significance). For serial correlation as detailed in Table 3, it was observe that the variables are not serially correlated (see the p-value of 0.94 ). Similarly, the Ramsey specification in Table 4 affirms that the model was well specified (see the p-value of 0.72 ). Multicollinearity issue was not detected by the inclusion of exchange rate and interest rate in the model as the correlation between them is 0.13 (see Table 5).

Table 2. Heteroskedasticity Test.

\begin{tabular}{llll}
\hline F-statistic & 1.410468 & Prob. F $(3,32)$ & 0.2577 \\
Obs*R-squared & 4.204379 & Prob. Chi-Square(3) & 0.2402 \\
\hline
\end{tabular}

Source: Data output via E-views 9.0

Table 3. Serial Correlation LM Test.

\begin{tabular}{llll}
\hline F-statistic & 0.060397 & Prob. F $(2,30)$ & 0.9415 \\
Obs*R-squared & 0.144372 & Prob. Chi-Square(3) & 0.9304 \\
\hline
\end{tabular}

Source: Data output via E-views 9.0
Table 4. Ramsey Reset Specification.

\begin{tabular}{llll}
\hline & Value & df & Probability \\
\hline t-statistic & 0.350355 & 31 & 0.7284 \\
F-statistic & 0.122748 & $(1,31)$ & 0.7284 \\
\hline
\end{tabular}

Source: Data output via E-views 9.0

Table 5. Correlation Matrix.

\begin{tabular}{llll}
\hline & Y & ER & IR \\
\hline Y & 1.000000 & 0.903217 & 0.239314 \\
ER & 0.903217 & 1.000000 & 0.139753 \\
IR & 0.239314 & 0.139753 & 1.000000 \\
\hline
\end{tabular}

Source: Data output via E-views 9.0

\section{Stationarity Test}

This study utilized the Augmented Dickey-Fuller (ADF) Test and Phillips Perron (PP) regression to check for stationarity of the variables: real gross domestic product growth (y), exchange rate (ER) and interest rate (IR). The stationarity test was conducted in level, first difference and in three sets: intercept, trend intercept and none. The nonstationarity of all the variables at level form resulted in the first difference test. The results of the ADF and PP tests show that all the variables are stationarity at first difference which clears the data of stationarity defect possessed by most time series data. The stationarity check for the data are presented in Tables 6-9.

Table 6. Result of ADF Test at Level.

\begin{tabular}{lllll}
\hline Variables & Intercept & Trend and Intercept & None & Remark \\
\hline Y & $0.524402(0.95)$ & $-1.363814(0.85)$ & $2.578270(0.99)$ & Not Stationary \\
ER & $2.044780(0.99)$ & $-1.139531(0.91)$ & $3.309145(0.99)$ & Not Stationary \\
IR & $-3.209519(0.02)^{* *}$ & $-3.199057(0.10)$ & $0.092650(0.70)$ & Not Stationary \\
\hline
\end{tabular}

Source: Data output via E-views 9.0

Note: The optimal lag for ADF test is selected based on the Akaike Info Criteria (AIC), p-values are in parentheses where $(*)$ and $(* *)$ denote significance at $1 \%$ and $5 \%$ respectively.

Table 7. Result of ADF Test at First Difference.

\begin{tabular}{lllll}
\hline Variables & Intercept & Trend and Intercept & None & Remark \\
\hline Y & $-5.528379(0.00)^{*}$ & $-5.573797(0.00)^{*}$ & $-3.962419(0.00)^{*}$ & Stationary \\
ER & $-5.432819(0.00)^{*}$ & $-5.883578(0.10)^{*}$ & $-1.947833(0.05)^{* *}$ & Stationary \\
IR & $-5.905075(0.00)^{*}$ & $-6.150503(0.00)^{*}$ & $-5.936443(0.00)^{*}$ & Stationary \\
\hline
\end{tabular}

Source: Data output via E-views 9.0

Note: The optimal lag for ADF test is selected based on the Akaike Info Criteria (AIC), p-values are in parentheses where $(*)$ and $(* *)$ denote significance at $1 \%$ and $5 \%$ respectively. 
Table 8. Result of PP Test at Level.

\begin{tabular}{lllll}
\hline Variables & Intercept & Trend and Intercept & None & Remark \\
\hline Y & $0.701577(0.99)$ & $-1.473548(0.82)$ & $3.587723(0.99)$ & Not Stationary \\
ER & $2.044780(0.99)$ & $-0.813770(0.95)$ & $3.309145(0.99)$ & Not Stationary \\
IR & $-3.142243(0.03)^{* *}$ & $-2.989640(0.14)$ & $-0.132810(0.63)$ & Not Stationary \\
\hline
\end{tabular}

Source: Data output via E-views 9.0

Note: In determining the truncation lag for PP test, the spectral estimation method selected is Bartlett kernel and Newey-West method for Bandwidth, p-values are in parentheses where $(*)$ and $(* *)$ denote significance at $1 \%$ and $5 \%$ respectively.

Table 9. Result of PP Test at First Difference.

\begin{tabular}{|c|c|c|c|c|}
\hline Variables & Intercept & Trend and Intercept & None & Remark \\
\hline $\mathrm{Y}$ & $-5.528379(0.00)^{*}$ & $-5.572466(0.00)^{*}$ & $-4.039774(0.00)^{*}$ & Stationary \\
\hline ER & $-5.455022(0.00)^{*}$ & $-5.897254(0.00)^{*}$ & $-1.947833(0.05)^{* *}$ & Stationary \\
\hline IR & $-9.476216(0.00)^{*}$ & $-9.918226(0.00)^{*}$ & $-9.510051(0.00)^{*}$ & Stationary \\
\hline
\end{tabular}

Source: Data output via E-views 9.0

Note: In determining the truncation lag for PP test, the spectral estimation method selected is Bartlett kernel and Newey-West method for Bandwidth, p-values are in parentheses where $(*)$ and $(* *)$ denote significance at $1 \%$ and $5 \%$ respectively.

\section{Co-integration Analysis}

The stationarity of the variables (see Tables 7 and 9) permits for ascertaining the number of co-integrating equation (s) between the variables. From the output in Table 10 , the first null hypothesis of no co-integrating relation would not be rejected at 5\% level of significance. Again, the second null hypothesis of less than or equal to 1 vector would not be rejected at 5\% level of significance against the alternate hypothesis as trace statistic of 12.89510 is less than the critical value of 15.49471 . The Johansen co-integration analysis discloses that there is no equilibrium long run relationship between real gross domestic product growth, exchange rate and interest rate in Nigeria. To statistically satisfy the disbelief of the Johansen co-integration result in
Table 10, Auto-Regressive Distributed Lag (ARDL) bound test was incorporated to determine the co-integration relationship between the variables. The revelation in Table 11 is that real gross domestic product growth, exchange rate and interest rate are not co-integrated (f-statistic of 1.424851 is less than the upper and lower bound of 4.85 and 3.79 respectively). The outcome of ARDL as shown in Table 11 supports the revelation of the Johansen analysis in Table 10. From the application of the Johansen co-integration and ARDL techniques, there is no equilibrium long run relationship between gross domestic product growth, exchange rate and interest rate in Nigeria hence, it become irrelevant to proceed to determining speed of adjustment to equilibrium via error correction mechanism.

Table 10. Result of Johansen Co-integration for Y, ER and IR.

\begin{tabular}{|c|c|c|c|c|}
\hline \multicolumn{5}{|c|}{ Unrestricted Co-integration Rank Test (Trace) Y, ER and IR } \\
\hline Hypothesized Number of CE (s) & Eigen Value & Trace Statistic & 0.05 Critical Value & Prob.** \\
\hline None & 0.240435 & 22.52042 & 29.79707 & 0.2704 \\
\hline At most 1 & 0.209841 & 12.89510 & 15.49471 & 0.1187 \\
\hline At most 2 & 0.124456 & 4.651839 & 3.841466 & 0.0310 \\
\hline \multicolumn{5}{|c|}{ Unrestricted Co-integration Rank Test (Maximum Eigen Value) Y, ER and IR } \\
\hline Hypothesized Number of CE (s) & Eigen Value & Maximum Eigen Statistic & 0.05 Critical Value & Prob.** \\
\hline None & 0.240435 & 9.625325 & 21.13162 & 0.7790 \\
\hline At most 2 & 0.124456 & 4.651839 & 3.841466 & 0.0310 \\
\hline
\end{tabular}

Trace test and Max-eigenvalue test indicate no co-integrating eqn (s) at the 0.05 level;

* denotes rejection of the hypothesis at the 0.05 level; **MacKinnon-Haug-Michelis (1999) p-values.

Table 11. Result of Bound Test for Y, ER and IR.

\begin{tabular}{llll}
\hline T-Test & $\mathbf{5 \%}$ Critical Value Bound & Implication \\
\hline F-Statistic & Lower Bound & Upper Bound & \\
1.424851 & 3.79 & 4.85 & Null Hypothesis Rejected \\
\hline
\end{tabular}

Source: Computer output data using E-views 9.0

\section{Model Estimation}

The model was estimated using the Auto-Regressive Distributed Lag (ARDL) method of estimation. From the result in Table 12, exchange rate and interest rate are negatively and insignificantly related with real gross domestic product growth. This is in line with a priori expectation based on the volatility of the variables concerned. The constant coefficient of 2361.66 entails that holding exchange rate and interest rate constant, real gross domestic product growth would stand at $¥ 2,361.60$ billion. A unit increase in exchange rate and interest rate result in $\$ 29.47$ billion and $\$ 42.51$ billion depreciation in real gross 
domestic product respectively. The result of the negative relationship (though insignificant) between real gross domestic product growth, exchange rate and interest rate is a clear affirmation of the devastating influence of exchange rate depreciation and high interest rate on real output. The Adjusted R-square reveals that $98.32 \%$ changes in real gross domestic product growth was explained by fluctuation in exchange rate and interest rate, and this is highly significant following the p-value $(0.00)$ of the f-statistic. There was no trace of autocorrelation in the model estimated as the Durbin statistic of 2.1 meets the statistical benchmark of no autocorrelation.

Table 12. ARDL Model Estimation Dependent Variable: Real Gross Domestic Product Growth.

\begin{tabular}{llll}
\hline Variable & Coefficient & Std. Error & t-Statistic \\
\hline Y (-1) & 0.966203 & 0.057948 & 16.67352 \\
ER & -29.47957 & 24.00924 & -1.227843 \\
ER (-1) & 50.32908 & 28.18603 & 1.785604 \\
IR & -42.51475 & 100.9106 & -0.421311 \\
C & 2361.660 & 1775.736 & 1.329961 \\
R-squared & 0.985083 & Mean dependent var & 0.2287 \\
Adjusted R-squared & 0.983158 & S. D. dependent var & 0.6764 \\
S. E. of regression & 2677.122 & Akaike info criterion & 0.1932 \\
Sum squared resid & $2.22 \mathrm{E}+08$ & Schwarz criterion & 29762.76 \\
Log likelihood & -332.5201 & Hannan-Quinn criter. & 20628.48 \\
F-statistic & 511.7746 & Durbin-Watson stat & 18.75112 \\
Prob (F-statistic) & 0.000000 & & 18.97105 \\
\hline
\end{tabular}

Source: Computer output data using E-views 9.0

\section{Determinants of Real Gross Domestic Product Growth}

This study utilized the granger causality test to ascertain whether or not exchange rate and interest rate determine real gross domestic product growth. The granger causality analysis shows the capacity of a variable to predict another. As shown in Table 13, there is no causal relationship between real gross domestic product growth, exchange rate and interest rate at $5 \%$ level of significance. Therefore, the null hypothesis that exchange rate and interest rate does not granger cause real gross domestic product growth could not be rejected owing to insignificant p-values (at 5\% level of significance) of exchange rate and interest rate. Consequently, from the result in Table 13, it is empirically obvious that exchange rate and interest rate does not determine real gross domestic product growth in Nigeria.

Table 13. Granger Causality for $Y, E R$ and IR.

\begin{tabular}{llll}
\hline Null Hypothesis: & Obs & F-Statistic & Prob. \\
\hline ER does not Granger Cause Y & 36 & 2.37857 & 0.1325 \\
Y does not Granger Cause ER & & 2.18022 & 0.1493 \\
IR does not Granger Cause Y & 36 & 0.89190 & 0.3518 \\
Y does not Granger Cause IR & & 0.06380 & 0.8022 \\
\hline
\end{tabular}

Source: Computer output data using E-views 9.0

\section{Discussion of Findings in Relation to Previous Studies}

The results of the analysis were discussed by relating it with previous studies. Firstly, by the application of Johansen co-integration and ARDL methodology, this study identified that exchange rate and interest rate are not cointegrated/related with real gross domestic product growth in the long run. This supports the work of [16] that in Bangladesh, exchange rate and interest rate are not related with real gross domestic product growth in long run at 5\% significance level. On the contrary, it rejects the findings of [18] and [20] who identified the presence of a long run relationship between real gross domestic product growth, exchange rate and interest rate in Malaysia and Nigeria respectively. Secondly, the multiple regression estimated via ARDL shows that exchange rate and interest rate have negative but insignificant relationship with real gross domestic product growth. The implication is that for Nigeria to ensure sustainability in gross domestic product growth, the exchange rate must be favourable while interest rate reduced to barest minimum to allow access to credit at low cost. This is in agreement with [8], [13], [20], [21], [22] and [27] for Nigeria, [15] for Kenya, [17] for 18 developing countries of the world, [23] for Pakistan and [28] on contractional effect of high interest rate on annual GDP of major industrial countries. Finally, through the Granger Causality analysis, it was empirically established that exchange rate and interest rate are not determinants of real gross domestic product growth in Nigeria. Following the report of National Bureau of Statistic on the real economy for the year 2016, the exchange rate crisis which still exists as at the time this study was carried out, deteriorated Nigeria real gross domestic product from $¥ 69,023.93$ billion in 2015 to $¥ 67,984.20$ billion in 2016. The inability of exchange rate and interest rate to predict growth in real gross domestic product of Nigeria is consistent with previous studies: [8], [13] and [27] for Nigeria, [16] for Bangladesh economy, [23] for Pakistan 
but disagrees with [18] who asserted that exchange rate significantly determines real gross domestic product in Malaysia.

\section{Conclusion and Recommendations}

The examination of exchange rate and interest rate as determinants of real gross domestic product in Nigeria was carried out to show that volatility in these fundamentals does not affect growth of the Nigeria economy. The monetary paraphernalia of the government is very relevant to realizing a target level of growth and development, particularly in developing economies which have some liquidity constraints affecting efficient and effective mobilization of resources through the financial system. The dynamics in these variables sharp or determine production pattern. In the present situation where Nigeria virtually imports all her needs, depreciation in the exchange rate and high interest rate would spell doom to the economy as costs of foreign consumption will be exorbitant while domestic production would be encumbered owing to high cost of capital.

Pursuant to the findings emanating from this study, to strengthen the value of Nigeria's local currency against the US dollar in particular and other currencies of the world, a well-managed foreign exchange floating system is preferred. To strategically via effective export policies, improving the nation's balance of payment position would enhance the real gross domestic product as this would help reduce further depreciation of the local currency against world major currencies. Diversification from oil to non-oil policies should be pursued with vigour with the view of aggressively down playing importation to reduce the pressure on forex which jolts up exchange rate position adversely.

\section{References}

[1] Anyanwu, F. A., Ananwude, A. C. \& Okoye, N. T. (2017). Exchange rate policy and Nigeria's economic growth: A granger causality impact assessment. International Journal of Applied Economics, Finance and Accounting, 1 (1), 1-13.

[2] Amer, C. \& Amer, D. S. (1984). Dictionary of business and economics. Macmillan Publisher, USA.

[3] Reinhart, C. M. \& Rogoff, K. S. (2009). Prices, exchange rate, currency debasement and real GDP in this time is different eight centuries of financial folly. Princeton University Press, USA.

[4] Ibenta, S. N. O. (2012). International Trade and Finance. Ezu Book Ltd, Enugu.

[5] Jhingan, M. L. (2003). Macroeconomic Theory. New Delhi, Nisha Enterprises.

[6] Obioma, E. C. (2014). External reserve management and utilization: Nigeria experience. CBN Bullion, 37 (2), 10-26.

[7] Chimobi, O. P. (2010). Inflation and economic growth in Nigeria. Journal of sustainable Development, 3 (2), 159166.
[8] Inam, U. S. \& Umobong, E. S. (2015). An empirical analysis of the relationship between exchange rate movements and economic growth in Nigeria. European Journal of Business and Management, 7 (30), 191-199.

[9] Akpan, E. O. \& Atan, J. A. (2015). Effects of exchange rate movements on economic growth in Nigeria. CBN Journal of Applied Statistics, 2 (2), 1-14.

[10] Ismaila, M. (2016). Exchange rate depreciation and Nigeria economic performance after Structural Adjustment Programmes (SAPs). NG-Journal of Social Development, 5 (2), 122-132.

[11] Amassoma, D. \& Odeniyi, B. D. (2016). The nexus between exchange rate variation and economic growth in Nigeria. Singaporean Journal of Business Economics, And Management Studies, 4 (2), 8-28.

[12] Obansa, S. A. J., Okoroafor, O. K. D., Aluko, O. O. \& Eze, M. (2013). Perceived relationship between exchange rate, interest rate and economic growth in Nigeria: 1970-2010. American Journal of Humanities and Social Sciences, 1 (3), 116-124.

[13] Onuorah, A. C. \& Osuji, C. C. (2014). Exchange rate and the economic growth in Nigeria. International Journal of Management Sciences, 2 (2), 78-87.

[14] Diabate, N. (2017). Causality between economic growth and changes of the real exchange rate in Côte d'Ivoire. Journal of Economics and International Finance, 9 (1), 1-11.

[15] Musyoki, D., Pokhariyal, G. P. \& Pundo, M. (2012). The impact of real exchange rate volatility on economic growth: Kenyan evidence. Business and Economic Horizons, (7) 1, 59-75.

[16] Uddin, K. M. K., Rahman, M. M. \& Quaosar, G. M. A. A. (2014). Causality between exchange rate and economic growth in Bangladesh. European Scientific Journal, 10 (31), 11-26.

[17] Basirat, M., Nasirpour, A. \& Jorjorzadeh, A. (2014). The effect of exchange rate fluctuations on economic growth considering the level of development of financial markets in selected developing countries. Asian Economic and Financial Review, 4 (4), 517-528.

[18] Kogid, M., Asid, R., Lily, J., Mulock, D. \& Loganathan, N. (2011). The effect of exchange rates on economic growth: empirical testing on nominal versus real. A paper was presented at the International Conference on Applied Business Research (ICABR), November 28 December 2, 2011, Johor Bahru, Malaysia.

[19] Eichengreen, B. (2007). The real exchange rate and economic growth. University of California, Berkeley. A prepared for the World Banks Commission on Growth.

[20] Obamuyi, T. M. (2009). An investigation of the relationship between interest rates and economic growth in Nigeria, 1970 2006. Journal of Economics and International Finance, 1 (4), 93-98.

[21] Fasanya, I. O., Onakoya, A. B. O. \& Agboluaje, M. A. (2013). Does monetary policy influence economic growth in Nigeria? Asian Economic and Financial Review, 3 (5), 635-646.

[22] Udoka, C. O. \& Anyingang, R. A. (2012). The effect of interest rate fluctuation on the economic growth of Nigeria, 1970-2010. International Journal of Business and Social Science, 3 (20), 295-302. 
[23] Tahir, S. H., Shehzadi, I., Ali, I. \& Ullah, M. R. (2015). Impact of bank lending on economics growth in Pakistan: An empirical study of lending to private sector. American Journal of Industrial and Business Management, 5, 565-576.

[24] Anaripour, J. T. (2011). Study on relationship between interest rate and economic growth by eviews (2004-2010, Iran). Journal of Basic and Applied Science Research, 1 (11), 23462352.

[25] Saymeh, A. A. F. \& Orabi, M. M. A. (2013). The effect of interest rate, inflation rate, GDP on real economic growth rate in Jordan. Asian Economic and Financial Review, 3 (3), 341354.

[26] Obadeyi, J., Akingunola, R. \& Afolabi, V. (2013). Interest rate targeting: A monetary tool for economic growth in Nigeria? Stakeholders' approach. Advances in Economics and Business, 1 (2), 103-123.

[27] Babalola, O. O., Danladi, J. D., Akomolafe, K. J. \& Ajiboye, O. P. (2015). Inflation, Interest Rates and Economic Growth in Nigeria. European Journal of Business and Management, 7 (30), 91-102.

[28] Giovanni, J. \& Shambaugh, J. C. (2008). The impact of foreign interest rate on the economy: The role of the exchange rate regime. Journal of International Economics, 74, 341-361.

[29] Jelilov, G. (2016). The impact of interest rate on economic growth example of Nigeria. African Journal of Social Sciences, 6 (2), 51-64.

[30] Gujarati, D. N. (2004). Basic Econometric. 4th Ed., New York, McGraw-Hill Inc.
[31] Danladi, J. D. \& Uba, U. P. (2016). Does the volatility of exchange rate affect the economic performance of countries in the West African Monetary Zone? A case of Nigeria and Ghana. British Journal of Economics, Management and Trade, 11 (3), 1-10.

[32] Lawal, E. M. (2016). Effect of exchange rate fluctuations on manufacturing sector output in Nigeria. Journal of Research in Business and Management, 4 (10), 32-39.

[33] Akinlo, O. O. \& Lawal, Q. A. (2016). Impact of exchange rate on industrial production in Nigeria 1986-2010. International Business and Management, 10 (1), 104-110.

[34] Ali, A. I., Ajibola, I. O., Omotosho, B. S., Adetoba, O. O. \& Adeleke, B. O. (2015). Real exchange rate misalignment and economic growth in Nigeria. CBN Journal of Applied Statistics, 6 (2), 103-131.

[35] Amassoma, D. (2017). The nexus between exchange rate variation and economic growth in Nigeria. Journal of Entrepreneurship, Business and Economics, 5 (1), 1-40.

[36] Oleka, C. D. \& Okolie, P. I. P. (2016). The impact of floating exchange rate regime on economic growth in Nigeria (19862015). Journal of Economics and Finance, 7 (5), 35-42.

[37] Etale, L. M. \& Ayunku, P. E. (2016). The relationship between interest rate and economic growth in Nigeria: An Error Correction Model (ECM) approach. International Journal of Economics and Financial Research, 2 (6), 127-131. 